KIDNEY TISSUE SOMATOMEDIN-C INCREASE AFTER NEPHREC-

0492 TOMY IS INDEPENDENT OF GROWTH HORMONE. Alan D. Stiles, A.J.D'Ercole and Barry T. Smith, Harvard Medical School, Boston and thiversity of North Carolina, Chapel Hill, Departments of Pediatrics.

Somatomedin-C $(\mathrm{SmC})$ is a peptide mitogen whose serum and tissue levels are considered to be growth hormone dependent. We previously reported that tissue $\mathrm{SmC}$ is significantly elevated in resent study, we measured $\mathrm{SmC}$ tissue levels in the surgically removed left kidney of 12 wk old hypophysectomized rats and in the remaining kidney 5 days later. Similar measurements were made on kidneys from hypophysectomized rats following sham surgery.

Nephrectomy $(n=6)$ Kidney Tissue SmC (units/gm $\pm \mathrm{SD}$ )

\section{right kidney}

Sham $(n=6)$

$$
\begin{aligned}
& 1.58 \pm 0.23 * \\
& 0.86 \pm 0.15 \quad *_{p}<.0001
\end{aligned}
$$

right kidney

$0.85 \pm 0.31$

left kidney

Serutn concentrations (nephrectomy: $1.17 \pm 0.17$ units/ml; sham: $1.09 \pm 0.21$ units $/ \mathrm{ml}$ ) were no different. Injection of ${ }^{125} \mathrm{I}-\mathrm{SmC}$ into nephrectomized and sham operated animals showed no difference in right kidney uptake 5 days after surgery.

Thus, SmC is increased in regenerating kidney tissue even in the absence of growth hormone. Since there was no change in renal uptake of labelled SmC, the changes observed do not reflect renal clearance. (Supported by NIH grant HL-25907) generating kidneys after contralateral nephrectomy. In the pre-

PREMATURE ADRENARCHE RESULIING FROM SYMPTOMATIC NON495 S Pang, MI New, The New York Hospital-Cornell Medical Among 25 patients ( 19 girls and 6 boys) with premature adrenarche, 21 -hydroxylase deficiency $(21-0 \mathrm{H}$ def) based on elevated ACTH stimulated 17 -hydroxyprogesterone (17-OHP) and decreased ratio of 17-hydroxypregnenolone $(\Delta 5-17 \mathrm{P}) / 17-0 \mathrm{HP} ; 2$ were suspected of having a partial adrenal $3 \beta$-hydroxysteroid dehydrogenase def $i$ ciency (3B-HSD def) based on high responses of $\triangle 5-17 P$ to ACTH stimulation and elevated ratio of $\Delta 5-17 \mathrm{P} / 17-0 \mathrm{HP}$. Elevated mor ning $\Delta 5-17 P$ in a 5 -year-old girl with $3 \beta-H S D$ def revealed diurnal variation. In all 7 patients with suspected genetic steroidogenic defects who received dexamethasone (dex), there was prompt suppression of elevated hormone levels. The remaining 15 patients with premature adrenarche did not have abnormalities in steroidogenesis, although some androgen levels were elevated and suppressed with dex, and those were classified as idiopathic. In conclusion, we propose that premature adrenarche with exces sive $\Delta 5$ and $\Delta 4$ steroid production in association with partial steroid enzyme defect is probably due to late-onset, nonclassical congenital adrenal hyperplasia, and this condition is prob-

\begin{tabular}{|c|c|c|c|c|c|c|}
\hline & $\frac{\operatorname{post} 250}{\Delta 5-17 p}$ & $\frac{1 \mathrm{~V} \text { Dolus }}{17-\mathrm{OHP}}$ & DHEA & $\Delta 4-A$ & & $\begin{array}{l}\triangle 5-1 / P P \\
17-O H P\end{array}$ \\
\hline $\begin{array}{l}\text { Normal (11) } \\
21-0 \mathrm{H} \text { def } \\
3 \text { BHSD def } \\
\text { Idiopathic }\end{array}$ & $\begin{array}{r}345 \pm 203 \\
876 \pm 516 \\
1699 \pm 323 \\
633 \pm 347\end{array}$ & $\begin{array}{c}302 \pm 166 \\
4244 \pm 1113 \\
237 \pm 98 \\
262 \pm 202\end{array}$ & $\begin{array}{l}120 \pm 164 \\
565 \pm 398 \\
602 \pm 40 \\
339 \pm 144\end{array}$ & $\begin{array}{c}52 \pm 80 \\
144 \pm 77 \\
86 \pm 8 \\
93 \pm 155\end{array}$ & $\begin{array}{l}19 \pm 22 \\
24 \pm 13 \\
32 \pm 33 \\
11 \pm 5\end{array}$ & $\begin{array}{c}2 \pm 2 \\
.21 \pm .09 \\
7.5 \pm 1.7 \\
3 \pm 1.5\end{array}$ \\
\hline
\end{tabular}
ably more comon than has been previously recognized.

MIMPAIRED 25-HYDROXYLATION OF VITAMIN D IN HEPATIC

193 CUSHING'S SYNDROFE NO HIRSUTISM OUE TO A MLIGNANT OVARIAM TUWOR, E Stoner, S Pang, A Berkley, SE, Oberfield, LS L.evine,
MI New, New York Hospital-Cornell Medical Center, New York, 1002

Ovarian tissue is classically devoid of 11ß-hydroxylase and 21-hydroxylase activity. We report a 19 -year-old female who presented with Cushing's syndrome, tumor autonomously producing cortisol (F). ACTH levels were within the normal range. Peripheral levels of $\triangle 4$-androstenedione $(\triangle 4-A)$ were markedly elevated. The tumor $r a s$ only minimally responsive to ACTH and neither glucocorticoid no production in the ovarian tissue was not under ACTH control. Upon removal of the tumor, androgen levela fell to within the normal range and serum $F$ returne to a normal circadian pattern. Excess facial hair vanished and menses resumed
within one month of tumor removal. Pathology was consistent with lipoid cell within one month of tumor removal. Pathology was consistent with lipoid cell
tumor of the ovary, but adrenocortical carcinoma arising in an ovarian-udrenal courses of chemotherapy with adriamycin, cis-platinum, and opOOD therapy. The

\begin{tabular}{|c|c|c|c|c|c|}
\hline & $F(\mu \mathrm{g} / \mathrm{dl})$ & $\Delta 4-\mathrm{A}(\mathrm{ng} / \mathrm{dl})$ & $Y(\mathrm{ng} / \mathrm{dl})$ & DHEA $(n g / d I)$ & ACTH (pgoml) \\
\hline baseline & 30 & 550 & 39 & 185 & $\begin{array}{l}30.7 \mathrm{a} . \mathrm{m} . \\
30.2 \mathrm{p} . \mathrm{m} .\end{array}$ \\
\hline post-Cortrosyn & 43 & 770 & 56 & 258 & \\
\hline $\begin{array}{l}\text { Dexamethasone } \\
2 \mathrm{mg} / \mathrm{d} \times 2 \times 2 \mathrm{~d} \\
8 \mathrm{mg} / \mathrm{d} \times 2 \mathrm{~d} d\end{array}$ & $\begin{array}{l}40 \\
40\end{array}$ & $\begin{array}{l}653 \\
757\end{array}$ & $\begin{array}{l}52 \\
62\end{array}$ & $\begin{array}{l}160 \\
301\end{array}$ & \\
\hline $\begin{array}{l}\text { post-op } \\
8 \mathrm{a} . \mathrm{m} . \\
4 \mathrm{p.m} .\end{array}$ & $\begin{array}{r}13.1 \\
4.9\end{array}$ & $\begin{array}{r}134 \\
78\end{array}$ & $\begin{array}{l}\text { undetect able } \\
\text { undetectable }\end{array}$ & $\begin{array}{l}309 \\
100\end{array}$ & $\begin{array}{l}42.3 \\
28.8\end{array}$ \\
\hline
\end{tabular}
hormonal results are tabulated below. We therefore report a metastat ic ovarian tumor resulting in Cushing's syn-
ome with autonomous cortisal secretion.
Idiopathic $633 \pm 347$
496 NECROSIS Marios Theodossiou, May Kung, Donald Fraser Univ of Toronto and Research Institute, Hospital for Sick Children, Toronto, Canada.

To evaluate the metabolism of vitamin $D$ in liver disease, in which 25 -hydroxylation may be low, vitamin $D$ deficient rats were divided into control and carbon tetrachloride $\left(\mathrm{CC}_{4}\right)$-treated groups. Treated rats received a single i.p. Injection of $\mathrm{CCl}_{4}$, $2.0 \mathrm{ml} / \mathrm{kg}$; controls recelved no $\mathrm{CCl}_{4}$. Twenty-four h later, the rats recelved i.v. $3 \mathrm{H}$-vitamin $\mathrm{D}_{3}$ at doses of 55,550 , or 5050 pmo1. $24 \mathrm{~h}$ later, aliquots of serum and liver were analyzed for $3 \mathrm{H}$-vitamin $\mathrm{D}_{3}, 3 \mathrm{H}-25-\mathrm{HD}_{3}$ and $3 \mathrm{H}-1,25-(\mathrm{OH}) \mathrm{D}_{3}$ by HPLC. Isolated kidney perfusions were performed to determine whether $\mathrm{CCl}_{4}$ had an effect on renal metabolism of vitamin $D_{3}$. Histology showed serum albumin were indicative of severe $\mathrm{CCl}_{4}$-induced 1 iver damage. Sera of $\mathrm{CCl}_{4}$-treated rats showed increased $3 \mathrm{H}$-vitamin $\mathrm{D}_{3}$ and $3 \mathrm{H}-25-\mathrm{OHD}_{3}$ but decreased ${ }_{3} \mathrm{H}-1,25(\mathrm{OH})_{2} \mathrm{D}_{3}$. Livers of $\mathrm{CCl}_{4}-$ treated rats contained more $3 \mathrm{H}-\mathrm{vitamin} \mathrm{D}_{3}$ and were heavily infiltrated with fat when compared to control. There was decreased $3 \mathrm{H}-1,25(\mathrm{OH})_{2} \mathrm{D}_{3}$ production in kidneys of $\mathrm{CCl}_{4}$-treated rats. The studies indicate that 25 -hydroxylating capacity was not impaired in $\mathrm{CCl}_{4}$-induced hepatic necrosis in the rat even when tested with supraphysiological doses of vitamin D. Impairment of $1,25-(\mathrm{OH}){ }_{2} \mathrm{D}_{3}$ synthesis was observed. Our results indicate the great reserve capacity of the liver to 25 -hydroxylate vitamin D. massive confluent hepatic necrosis in $\mathrm{CCl}_{4}$-treated rats. Elevated levels of SGOT, SGPT and total bilirubin, and decreased levels of
MCCUNE ALBRIGHT SYNDROME - EVIDENCE OF AUTONOMOUS

494 ENDOCRINE FUNCTION. Dinesh Talwar, Indu Agarwal, Varma, Texas Tech University Health Sciences Center, Department of Pediatrics, Lubbock, Texas.

The origin of sexual precocity in McCune Albright Syndrome is still in question, whether hypothalmic or ovarian in origin. We studied a 5 year old girl who presented with breast enlargement, episodes of menstrual bleeding, pubic and axillary hair and right sided facial prominence. She had radiological evidence of polyostotic fibrous dysplasia and ultrasound evidence of ovarian cysts. A Neuroendocrine workup was done which demonstrated low basal levels of LH and FSH and failure to respond to GnRH, but her Serum Estradiol levels on two occasions were elevated $(52 \mathrm{pg} / \mathrm{ml}$ and $18 \mathrm{pg} / \mathrm{ml}$ )

\begin{tabular}{llllllllll} 
& & \multicolumn{2}{c}{ GnRH } & Stimulation & Test & & & \\
\cline { 2 - 9 } & 0 & 15 & 30 & 45 & 60 & 75 & 90 & \\
Mins & $<1$ & $<1$ & 2 & 2 & 3 & 3 & 4 & $\mathrm{mIU} / \mathrm{ml}$ \\
LH & $<3$ & $<3$ & 5 & 7 & 4 & 6 & 7 & $\mathrm{mIU} / \mathrm{ml}$
\end{tabular}

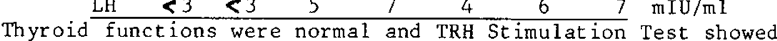
a normal TSH and Prolactin response. Somatomedin-C by RIA was $2.7 \mathrm{U} / \mathrm{ml}$ (Normal $0.8-2.4$ ). Serum Cortisol was normal. Wedge resection of the ovaries was done after which her Estradiol fell to $9 \mathrm{pg} / \mathrm{ml}$ and there has been regression in her breast size, no further menstrual bleeding and no evidence of progression of sexual precocity during short term follow up. Our studies and follow up indicate that the sexual precocity in McCune Albright Syndrome is ovarian in origin. Long term follow up is continuing.
DEHYDROEPIANDROSTERONE SULFATE (DS) IN NEWBORNS WITH

497 ABNORMAL GROWTH PATTERNS. Jeffrey E. Thompson, Davi A. Clark, Donald $W$. Chandler, Gregory Berg, Darrel Mayes. Dept. Of Pediatrics, SUNY, Upstate Med. Ctr., Syracuse, NY, and Endocrine Sciences, Tarzana, CA. Spon. M. L. Williams.

To examine the link between DS and fetal growth patterns, DS was measured by RIA following enzymolysis in 178 cord sera of twins, triplets, infants of diabetic mothers (IDM's), LGA newborns of non IDM's, and SGA newborns. Normal levels for AGA preterm and term infants were generated and agreed with previously published data, (29-35 wks. Mean DS $139 \pm 59$ vs term mean DS $234 \pm 39 \mathrm{p}<.01)$. DS did not vary with mode of delivery. AGA premature infants of multiple gestation pregnancies had significantly lower levels in the 35 wh group (74 732 vs $139 \pm 59$ $p<.01)$, in the $36-37$ wk group $(119 \pm 51$ vs $190 \pm 60 p<.01)$ and in the term group $(156 \pm 36$ vs $234 \pm 87 \mathrm{p}<.01)$. Furthermore, the sum of the DS in AGA twins was not significantly different than that of the mean values for singletons at matched gestational ages despite twice the adrenal tissue. In 4 of 5 discordant twin pairs the growth retarded twin had a much lower cord DS.

The DS did not differ between term LGA IDM infants (classes $A-C)$ and term non- $10 M$ 's $(211 \pm 53$ vs $234 \pm 87)$ al though non IDM LGA infants had higher DS ( $M 295 \pm 42$ vs $211 \pm 53 \mathrm{P}<.05)$. Term SGA infants without major congenital anomalies had lower DS than term AGA infants $(125 \pm 16$ vs $234 \pm 87 \mathrm{p}<.01)$.

DS in cord sera closely parallels the abnormal growth of non-IDM LGA or SGA infants and depressed levels precede the fall in the growth rate of multiple gestational births. 